\title{
EMOTIONAL AND PERSONAL FACTORS OF ADAPTABILITY OF THE POPULATION IN THE ECUADORIAN ANDES
}

\author{
Anna I. Costales Zavgorodniaya \\ Pontifical Catholyc University of Ecuador \\ 12 de Octubre \# 1076 y Roca, Quito, Ecuador, 170525
}

\begin{abstract}
The multidisciplinary and transdisciplinary principle has been applied to understand and interpret the perception and adaptability of the high Andes population to the climatic variability. The study is centered on several communities of the three ethno-cultural groups in Ecuador: Puruhas, Kayambis and Otavalos, linked to the two geographic sceneries, from $2600 \mathrm{~m}$ a.s.l. up to the summit of volcanoes. The information has been collected and the climatic variability along the last 30 years is analyzed, the dynamics of land use and natural vegetal covering of the two last decades have been interpreted (verified data and information), and data from real environment have been compared with the information obtained from the conversations, conducting surveys (perceived environment and people's answers) and psychological tests (behavior and analysis of adaptability). The study takes the perspective that adaptability is linked with the emotional and personal characteristics of the resilience of one person or one group. The capacity to get related with the environment, to take the greatest advantage from what is necessary in order to satisfy their needs, is a process through which the communities assimilate new ways of survival and, consequently, they adapt themselves to new situations. Studying these characteristics in a certain ethno-cultural group was the object of this study, and, in this paper we will show some of the characteristics as an attempt to make a possible model of the adaptational potential of the inhabitants of these groups in condition of hazard, and their possible vulnerability.
\end{abstract}

Key words: emotional and personal factors, adaptability, Ecuadorian Andes, multicultural comparative analysis

\section{Introduction}

Each culture has its own conceptions, relationships and perceptions about nature and its territories, as well as about the history of environmental changes, including climatic, which had happened before the history of human species started (Heyd, 2011, quoted by Pinilla Herrera, Rueda, Pinzón \& Sánchez, 2012). In this context the topic of the adaptation to such changes is not unknown for societies, because the different ways of understanding, perceiving and acting facing the atmospheric behavior and climatic phenomena, had allowed to transform and keep the social practices of environmental and productive management, across the time.

In order to have a better understanding of the psychological consequences which can come out from catastrophic events, it is helpful to review briefly the way how people get and develop the capacity to confront certain difficult situations in their lives and, how they get ready to survive successfully the exceptional painful experiences. These experiences 
generate temporary reactions which have variable duration and act as mechanisms of defense and, in some way, alert and prepare the person to face a traumatic situation, having a physical or emotional origin. Generally, these reactions to stress are closely related with learning, and become a survival mechanism and a kind of relief for the emotional tension. The learning process allows developing defense and molding of a stronger personality ready to face and overcome successfully the adversities which are presented. This process used to be built up in the family and community environment which, in normal conditions, are transformed in places which make it easy for the children and young people to grow in order to become independent and self-confident adults. The family, as a means protection and as a model, allows the child to absorb the healthy behaviors which older people are in capacity to give. On the other hand, the social group they belong to also supplies an adequate supporting net for the families and individuals. The total of those experiences acquired during the childhood and the adolescence, establishes the bases for the personality and contributes to the development of what is known as "resilience" (Rodríguez \& Zaccarelli Davoli, 2006).

In spite of the differences regarding terminology, resilience tends to be understood as a process which is conditioned by individual and environmental factors which come together in order to produce an exceptional reaction facing an important menace (Villalba Quesada C., 2004). The adaptation is related to the resilience (English word), which is a widely observed phenomenon, but, which has been given very little attention, including the two relevant aspects: to resist the event and to recover it (Bonanno, Wortman et al., 2002; Bonanno \& Kaltman, 2001). Faced with a traumatic event, resilient people get to keep a balance which is established without affecting their performance and their everyday work. Different from those who recover themselves in a natural way after a dysfunctional period, the resilient people don't go through this period, but remain functional regardless of the traumatic experience (Poseck, Baquero \&Vecina Jiménez, 2006).

This phenomenon is considered as something hard to believe or suitable for exceptional people (Bonanno, 2004) and, however, sufficient data show that resilience is a common phenomenon among the people who face adverse experiences and, stop functioning, unable to use the normal adaptive processes of human beings (Masten, 2001). The testimony of many people reveals that, even when they survived a traumatic situation, they got to face it and continue developing with efficiency in their environment (Poseck, Baquero \& Vecina Jiménez, 2006).

Any change in the person's environment requires that each individual takes certain steps, conscious or unconscious, in order to reach an effective level of adaptation to the occurred changes, this process is directly related to the resilient characteristics that have been developed by the individual during his life due to his physic, psycho-emotional and social environment.

Nevertheless, beyond conceptualizations, this research stands for the idea that an individual's autonomous adaptation or a community with its own identity, is able to solve and minimize the problems originated by the climatic change; without doubting the demonstrated human adaptability, it is claimed that there are limits or irregularities that may damage the response capacity (resilience) even in a population which has great abilities. That is why, the topic of the human adaptability as a management solution facing the climatic change, is a complex and up-to-date one. 
The set of the emotional and personality characteristics, which has been studied in this research represents the quantitative and qualitative characteristics which reflect the scope of the adaptation of the different cultural groups analyzed.

The emotional and personality factors, about the scope of adaptation, that is to say of the adaptability of the studied groups, reflect their inner psychological state, as well as, the psychosomatic manifestations and their energetic level, which is directly related to the physical health. This set of indicators allows to evaluate the scope of adaptation, to give the support to the adaptive process and to make the adequate corrections to the programs for crisis intervention.

For these reasons, in the process of adaptation to the conditions of individualenvironmental interaction, the problems of "psychological vulnerability", the prevention of the stress impact and its consequences acquire great importance, as well as the necessary maintenance of physical and mental health in order to approach the daily activities successfully.

However, this can be restrained by the population vulnerability in case of Climatic Change. The IPCC (2001) defines Climatic Change as "The level to which a system is susceptible or is not able to sustain the adverse effects of climatic change, including the climatic variability and the extreme phenomena. The vulnerability depends on the type, amount and speed of the climatic variation to which a system is exposed, considering its sensibility and its adaptation capacity" (IPCC, 2001).

From this premises, the interest to analyze not only the adaptation but the adaptability comes out, with the scope to the adaptation of the individuals and some collective ethnic and cultural groups, in order to share and face positive and traumatic experiences, and even more to get a benefit from them, considering on some occasions, that surviving a traumatic event presents an opportunity to take a conscious effort and remake the way of perceiving the world.

Based on the performed researches, all the factors involved in the adaptation and the personal characteristics of the resilience, would be understood through the adaptation strategies of the people and would vary, depending on the environment in which such a process happens.

The research about people's adaptation strategies in different natural and social environments, would offer the possibility to evaluate the personal adaptation potential and the improvement of these strategies, which, in its turn, could generate mechanisms of support in order for the experience not to be traumatic and, if it were, to help to propose the individual's growth and the development of their personal qualities (Costales, 2013).

\section{Methodology}

The two selected areas of research are the emblematic volcanos in the Ecuadorian Andes, in South America (Fig. 1).

Sample. The first area covers the coalescence of Chimborazo volcano with six thousand three hundred and ten meters above sea level and Igualata volcano (4214 masl), and are populated predominantly by people from the PURUHAS communities. The people from nine of these communities participated in the research (41 Puruhas, adults older than 40 years old, from rural research areas). The second research area is the basin of San Pablo Lake or Imbakucha, with its reflecting pool at two thousand six hundred forty meters 
above sea level. The lake is surrounded by four volcanoes: Imbabura (4621), Cubilche (3802), Cusín (3923) and Mojanda (4279). This area has significant cultural diversity of two cultural groups: OTAVALOS and KAYAMBIS. The people from six Kayambis communities and from eight Otavalos communities participated in the research (36 Otavalos and 35 Kayambis, adults older than 40 years old, from rural research areas).

Chimborazo
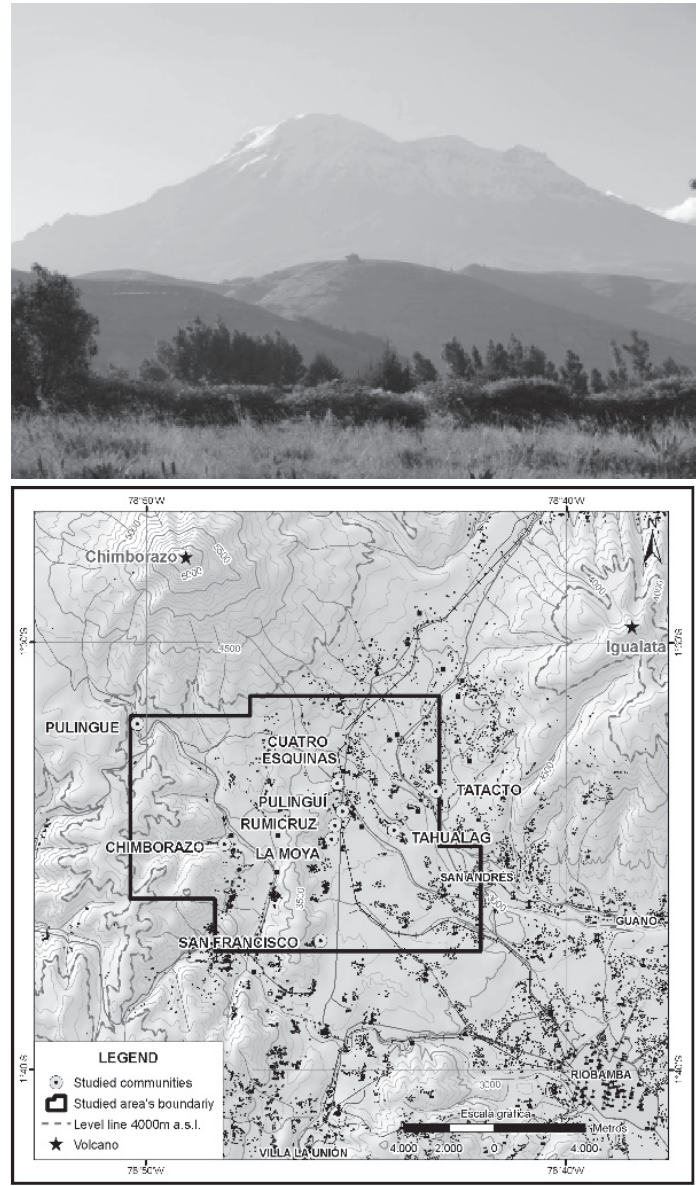

San Pablo Lake's basin
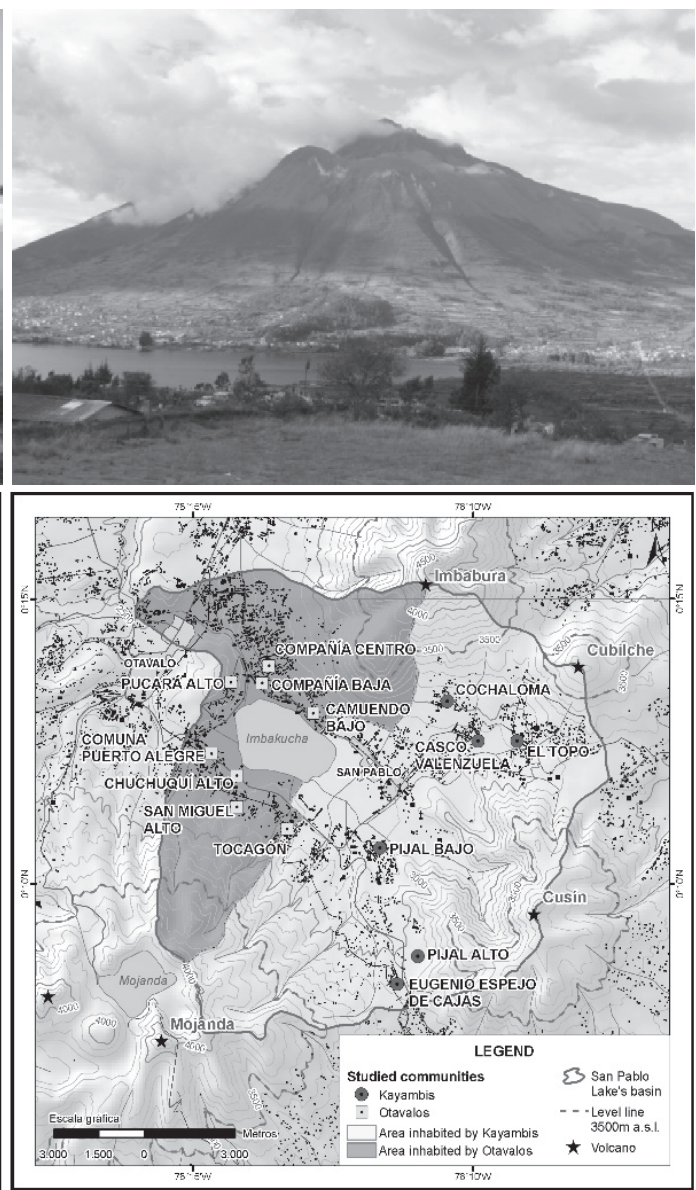

Fig. 1. Photographs and maps of the location of the research areas (Enríquez, 2014)

Instruments. For the analysis of the emotional and personal adaptability factors several research methods were used:

— The "Self Portrait" method (Besedin, Lipatov, Timchenko, \& Shapar', 1996: 203— 207).

— The "Who am I?" method (Rumyantseva T.V., 2006).

- Survey of the questionnaire "Psychosomatic symptoms" (created for this investigation, based on materials from Mikhailova, Costales Zavgorodniaya, 2011).

- M. Liusher's test: "Color selection diagnostic" (Timofeev, Filimonenko, 1995).

- Janoff-Bulman's "Shattered assumptions" or "Scale of basic concepts" (JanoffBulman R., 1992). 
The results of this data were analyzed with statistical instruments like percentage analysis, the Kruskal-Wallis difference criterion, cluster analysis of different groups using Ward's method and others.

\section{Results}

The projective method: "Self-portrait" adapted by R. Bernsom from the Institute of human development in Seattle (USA), consists in having the individuals draw themselves, this allows to have an insight into their cognitive and emotional components and helps to build a basic psychological portrait, for the interpretation of the obtained information whit other methods.

Fig. 2 shows the examples of the results of the "Self-Portrait" Method of the Puruhas, Kayambis and Otavalo people. Some of the information obtained based on the group results is:

- While the balance between dependence and independence, is quite widespread in the studied communities, most of them are comfortable and well suited in their own cultural environment.

- The Puruhas (Chimborazo) are willing to communicate openly with people worldwide, but at the same time have more difficulty in relating to the people outside their community.

- In all the three groups there is a tendency for idealism, spirituality and intellectuality, opposed to the reality they live in.
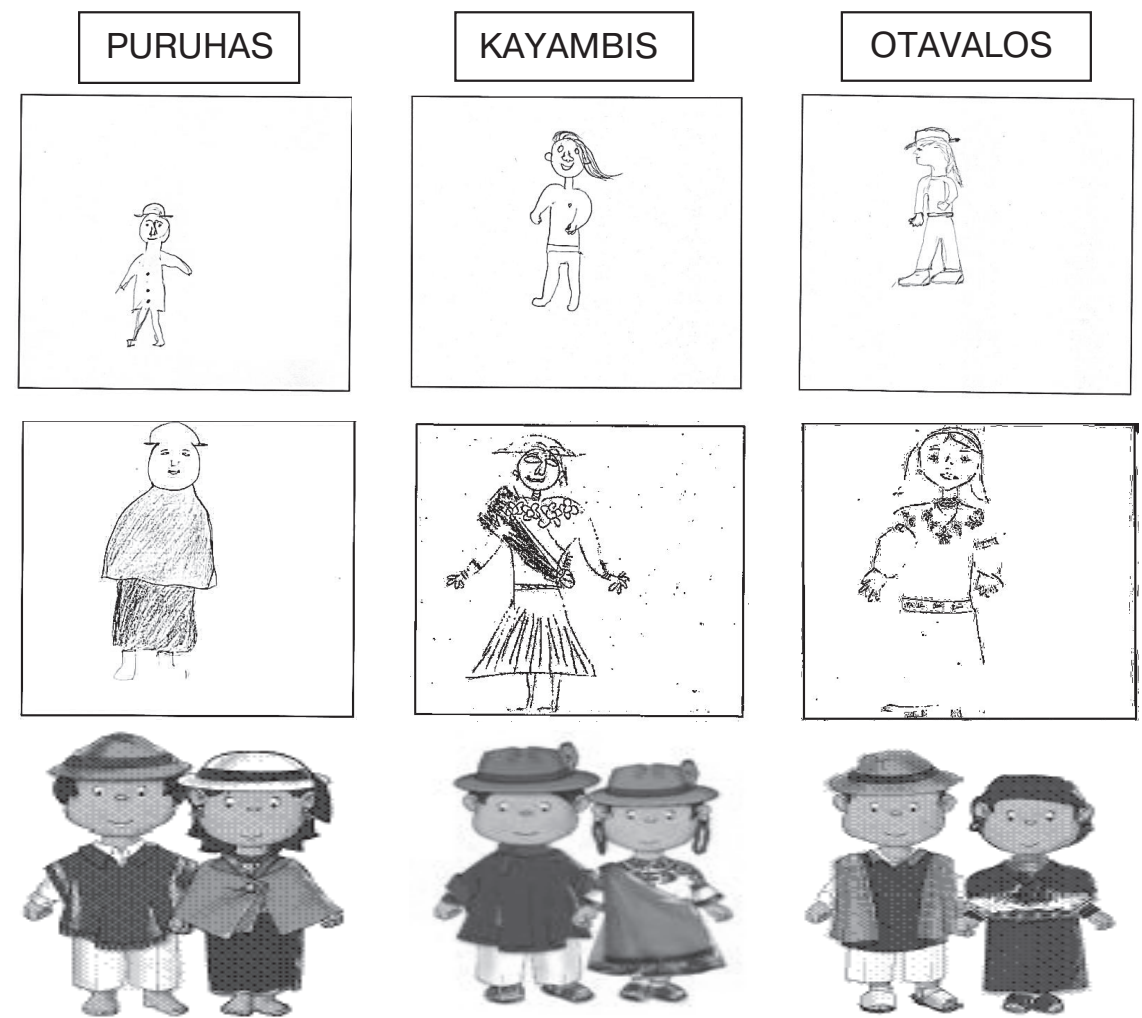

Fig. 2. Examples of the "Self-Portrait" Method Results and a graphic of the typical dress of each ethnic group 
Fig. 3 shows the percentage results of the "Who am I?" Method of the Puruhas, Kayambis and Otavalo people. The results of the analysis of the three groups, emphasized that, with the application of this method, we are able to highlight the following general conclusions:

- In the Kayambis and Otavalos communities, greater importance is given to the prospection and future, as well as the cognitive knowledge.

- In the Puruhas communities there are no responses over "material self," unlike the other two groups.

- In the "physical self" there is a similar percentage in all the three groups. This quality can be related to the fact that these communities give little thought to their individual decisions and preferences. This trend is more evident in the Puruhas than among the Kayambis and Otavalos.

- "Actor self," is proportional in all the three groups, this demonstrates a general tendency to give importance to their work activities as a fundamental part of their identity.

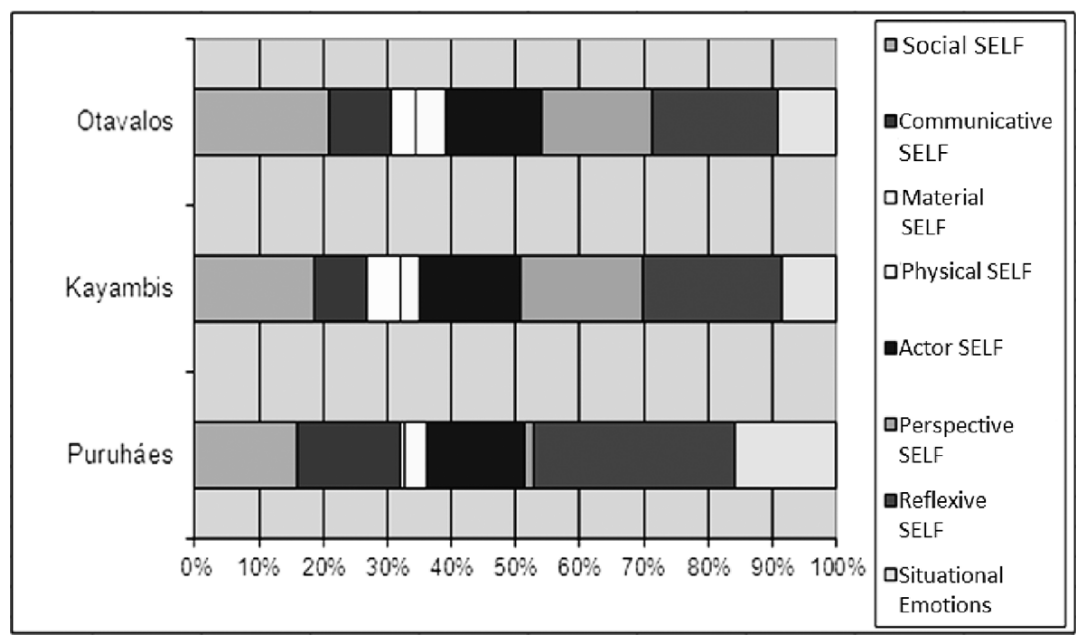

Fig. 3. "Who am I?" Method results

In order to obtain the information about the health of the inhabitants of the high mountain during the last ten years and about the changes of this state, a survey about "Psychosomatics symptoms" better known in the scientific literature of maladaptation is used; and the dynamics of these symptoms is analyzed in each of the studied groups. The survey respondents were interviewed being asked about the opinion they have or have had about this type of symptoms and, in case of having them, when they consider these symptoms appeared. The characteristics obtained using the survey on "Psychosomatic symptoms", show that, over time, the health status of the respondents has changed as follows in Table 1.

Table 1

Percentage results of the questionnaire "Psychosomatic symptoms"

\begin{tabular}{|c|l|c|c|c|}
\hline Psychosomatic symptoms & \multicolumn{1}{|c|}{ During the: } & Puruhas & Kayambis & Otavalos \\
\hline \multirow{4}{*}{ Memory problems } & Past 10 years & 10 & 6 & 8 \\
\cline { 2 - 5 } & Past five years & 24 & 40 & 17 \\
\cline { 2 - 5 } & Present & 49 & 63 & 64 \\
\hline
\end{tabular}


Table 1 (End)

\begin{tabular}{|c|c|c|c|c|}
\hline Psychosomatic symptoms & During the: & Puruhas & Kayambis & Otavalos \\
\hline \multirow{3}{*}{ Sleep problems } & Past 10 years & 7 & 6 & 11 \\
\hline & Past five years & 10 & 20 & 11 \\
\hline & Present & 37 & 49 & 39 \\
\hline \multirow{3}{*}{ Headaches } & Past 10 years & 15 & 17 & 11 \\
\hline & Past five years & 34 & 20 & 19 \\
\hline & Present & 68 & 46 & 53 \\
\hline \multirow{3}{*}{ Dizziness } & Past 10 years & 5 & 17 & 6 \\
\hline & Past five years & 22 & 23 & 6 \\
\hline & Present & 51 & 51 & 22 \\
\hline \multirow{3}{*}{ Heartaches } & Past 10 years & 10 & 14 & 6 \\
\hline & Past five years & 24 & 20 & 14 \\
\hline & Present & 24 & 31 & 39 \\
\hline \multirow{3}{*}{ Stomach and digestion problems } & Past 10 years & 22 & 17 & 19 \\
\hline & Past five years & 32 & 26 & 22 \\
\hline & Present & 63 & 31 & 44 \\
\hline \multirow{3}{*}{ Hyperactivity } & Past 10 years & 2 & 9 & 6 \\
\hline & Past five years & 7 & 6 & 3 \\
\hline & Present & 15 & 6 & 3 \\
\hline \multirow{3}{*}{ Fatigue } & Past 10 years & 2 & 14 & 11 \\
\hline & Past five years & 20 & 29 & 17 \\
\hline & Present & 61 & 46 & 39 \\
\hline \multirow{3}{*}{$\begin{array}{l}\text { Emotional imbalance and constant } \\
\text { mood swings }\end{array}$} & Past 10 years & 15 & 17 & 14 \\
\hline & Past five years & 27 & 17 & 17 \\
\hline & Present & 56 & 26 & 8 \\
\hline \multirow{3}{*}{ Communication problems } & Past 10 years & 7 & 6 & 11 \\
\hline & Past five years & 10 & 9 & 11 \\
\hline & Present & 12 & 11 & 17 \\
\hline \multirow{3}{*}{ Depression } & Past 10 years & 10 & 11 & 8 \\
\hline & Past five years & 20 & 11 & 8 \\
\hline & Present & 34 & 26 & 22 \\
\hline \multirow{3}{*}{ Denial of problems } & Past 10 years & 5 & 11 & 8 \\
\hline & Past five years & 2 & 11 & 8 \\
\hline & Present & 2 & 14 & 8 \\
\hline \multirow{3}{*}{ Anguish, anxiety and insecurity } & Past 10 years & 7 & 23 & 17 \\
\hline & Past five years & 22 & 23 & 19 \\
\hline & Present & 44 & 37 & 42 \\
\hline
\end{tabular}

During the past 10 years, the symptoms related to "stomach and digestion problems, heartaches, headaches and memory problems" have increased in all the three groups. In Chimborazo, the cases of "anguish, anxiety, insecurity and fatigue" have increased. The cases of "communication problems, dizziness and sleep problems" have increased among the Kayambis. Among the Otavalos the symptoms of "anguish, anxiety, insecurity and fatigue" have increased.

In the last five years, the symptom of "Depression" has grown in all the groups. The cases of "communication problems, dizziness and sleep problems" have increased in Chimborazo. The symptoms of "anguish, anxiety, insecurity, denial of problems, emotional imbalance, constant mood swings and fatigue" have grown among the Kayambis. The 
cases of "communication problems, dizziness and sleep problems" have increased among the Otavalos. Instead, over the past 10 years, the same symptoms of "denial of problems" have remained in the Puruhas and Otavalos.

In order to study and understand the "Neuro psychic tension level" and the "Energetic state" of the population, we compared the level of these qualities using the Kruskal-Wallis difference criterion (see Table 2). Their energy state is close to the ideal. These features make them very adaptable to future circumstances and help them to respond to emergency situations fast enough. Based upon the statistically valid differences obtained with the help of the Kruskal-Wallis difference criterion, we can conclude that in "neuro psychic level of tension" and "energy state", there is no difference between the groups.

Table 2

Results of the Kruskal-Wallis difference criterion in the scales of "Color selection diagnostic" (Based on M. Liusher's Test)

\begin{tabular}{|c|c|c|c|c|c|}
\hline \multirow{2}{*}{ Scales / Studied group } & \multicolumn{3}{|c|}{ Medians } & \multirow{3}{*}{$\begin{array}{c}\text { Kruskal Wallis } \\
\text { Criterion }\end{array}$} & \multirow{3}{*}{ P-leve } \\
\hline & Puruhas & Kayambis & Otavalos & & \\
\hline Quantity & $N=41$ & $N=35$ & $N=36$ & & \\
\hline Neuro psychic tension level & 3 & 4 & 4 & 2.42 & .29 \\
\hline Energetic state & 4 & 4 & 4 & 0.55 & .76 \\
\hline
\end{tabular}

Based on the colors chosen first and last, it is worth to notice certain trends that distinguish the population of each of the regions studied. Among the Puruhas, in the first place, green is the color of greatest choice (32\%), followed by red and yellow (20\% each), blue (10\%), purple (7\%), black and gray (5\% each) and brown (2\%). In the last place, for this group, gray is the color of greatest choice (39\%), followed by black (32\%), yellow and purple (7\% each), green and brown (5\% each), blue and red ( $2 \%$ each). Among the Kayambis, in the first place, purple is the color of greatest choice $(31 \%)$, followed by green $(26 \%)$, blue $(17 \%)$, red $(11 \%)$, brown, black and gray are not chosen $(0 \%)$. In the last place, for this group, black is the color of choice $(37 \%)$, followed by gray $(26 \%)$, yellow (11\%), purple (9\%), green blue and brown (6\% each), and red $(0 \%)$. Among the Otavalos, in the first place, red is the color of the greatest choice $(25 \%)$, followed by purple $(19 \%)$, blue (17\%), yellow (14\%), black and gray (8\% each), brown (6\%) and green $(3 \%)$. In the last place, for this group, black is the color of greatest choice $(36 \%)$, followed by gray $(19 \%)$, green and brown $(11 \%$ each), blue $(8 \%)$, purple and red $(6 \%$ each) and yellow (3\%) (see Table 3$)$.

Table 3

Percentage of choice of the different colors in the first and last places in the Puruháes, Kayambis and Otavalos population

\begin{tabular}{|c|c|c|c|c|}
\hline \multirow[b]{2}{*}{ Studied group } & \multicolumn{2}{|c|}{ Color preference } & \multicolumn{2}{|c|}{ Color denial } \\
\hline & $\begin{array}{l}\text { Greatest percen- } \\
\text { tage of choice in } \\
\text { each group }\end{array}$ & $\begin{array}{l}\text { Lowest percentage of } \\
\text { choice in each group }\end{array}$ & $\begin{array}{l}\text { Greatest percen- } \\
\text { tage of choice in } \\
\text { each group }\end{array}$ & $\begin{array}{l}\text { Lowest percentage of } \\
\text { choice in each group }\end{array}$ \\
\hline Puruhas & Green 32\% & Brown 2\% & Gray 39\% & Blue and Red $2 \%$ each \\
\hline Kayambis & Purple 31\% & $\begin{array}{l}\text { Brown, Black and Gray } \\
0 \% \text { each }\end{array}$ & Black 37\% & Red 0\% \\
\hline Otavalos & Red $25 \%$ & Green 3\% & Black $36 \%$ & Yellow 3\% \\
\hline
\end{tabular}


Among the Puruhas, it is remarkable: the search for self-realization, the rise of position, the desire to get power, respect, recognition, superiority, security, independence and the ability to defend themselves would be the necessity on which a third of its inhabitants is focused, as well as the desire to maintain an active attitude to situations around them. Among the Kayambis, the achievement of unity, identification with someone, the achievement of erotic and aesthetic goals, the desire to please others, to attract attention, make an impression and receive acceptance, seem to be the central motivations of almost a third of its inhabitants, but also there is denial and repression of aggression. Among the Otavalos, making achievements, maintaining the initiative, moving forward, being active, fighting and feeling emotions, are the main motivations of a quarter of its population, while, denial and repression of aggression are significant for more than a third of them. On summarizing the information obtained through this method, the respondents were classified into different risk groups according to their level of neurophysiological tension (see Table 4).

Table 4

Percentage analysis of the risk groups according to their level of neurophysiological tension

\begin{tabular}{|l|c|c|c|}
\hline \multicolumn{1}{|c|}{ Neuro-psychological stress level } & Low risk & Medium-risk & High-risk \\
\hline Puruhas & $59 \%$ & $29 \%$ & $12 \%$ \\
\hline Kayambis & $34 \%$ & $49 \%$ & $17 \%$ \\
\hline Otavalos & $45 \%$ & $25 \%$ & $30 \%$ \\
\hline
\end{tabular}

According to the parameter of neuro-psychological stress level, it can be concluded that the groups with higher risk are the Otavalos and Kayambis, because the highest percentage of the Kayambis, is in the medium-risk group; in turn, the Otavalos have a third of its population in the high risk group. These two groups are less able to perform their work, and have even less ability to act and less effectiveness than the population of the Puruhas (Chimborazo). From this it follows that:

The respondents belonging to the high-risk group are those who have a very high level of neurophysiological stress, they are almost exhausted, their level of awareness is sporadic and they are usually characterized by suffering from «binding» in certain negative emotional states. They show an absence of reasons hierarchy, the mood of the individual permanently changes and general emotional state is loaded by such feelings as anxiety, anguish, weakness, tiredness, lack of energy and peacefulness; in extreme situations, this kind of people are unpredictable and unreliable.

The respondents from the medium-risk group have obviously also a medium level of unproductive neuro-psychic tension, the individual is active and effectively fulfills his/ her activities and obligations as long as they belong to the usual context, passing with no problem through the states of work - break - work. If necessary, the respondents are able to overcome fatigue, thanks to having a willpower that helps them to maintain selfcontrol of their negative emotional states, but, after an effort, their condition and health status need a period of rest to return to normal and recover their working capabilities. With proper motivation, people with these characteristics can work for a long period and, in extreme situations, can be mobilized effectively and concentrate on safety requirements, as long as their energy is not in a phase of exhaustion. 
The respondents with low risk are characterized by a somehow insignificant level of unproductive neuro-psychic tension, in this case the people have the tendency to work actively, their energy resources are sufficient to achieve high peaks of activity and stress. When their activities and work are well-motivated and they find it interesting, these people have no difficulty learning and memorizing information during the process. In stressful situations, they can behave calmly and work out the situation. On the basis of the information obtained through this method, the respondents are classified into different risk groups according to their energy state (see Table 5).

Table 5

Percentage analysis of the risk groups according to their energy level

\begin{tabular}{|l|c|c|c|}
\hline \multicolumn{1}{|c|}{ Energy level } & Low risk & Medium-risk & High-risk \\
\hline Puruhas & $61 \%$ & $36 \%$ & $2 \%$ \\
\hline Kayambis & $51 \%$ & $46 \%$ & $3 \%$ \\
\hline Otavalos & $61 \%$ & $36 \%$ & $3 \%$ \\
\hline
\end{tabular}

Thanks to the parameter of the energy state, it can be concluded that the three groups have a fairly high energy level and the people's reaction at critical or stressful moments, will also be quite effective from the perspective of energy they have to show in the presence of the above mentioned circumstances.

The respondents of the high risk group are energetically worn out, with no strength and they need rest. People with this score are characterized by experiencing passive reactions to problems, they are not ready for a situation of stress and, at critical moments, generally adopt inappropriate behavior.

Those belonging to the medium-risk group, in turn, can form two groups:

- Those who are ready to use their energy optimally, but they need to take a break, since its current level is not precisely high, but enough to undertake their daily activities. In extreme situations, probably they adopt passive behavior and react slowly, especially in decision-making situations;

- Those with the excess of energy have exalted behavior, their activities take the form of relief from excessive energy and, in critical situations, they often behave impulsively, with ill-considered behavior without self-control. In extreme situations they demonstrate low effectiveness and suffer panic attacks.

Those who form the low-risk group have an optimum level of physical and mental resources to act; in extreme situations they probably react quickly and positively, it is common for them to take the right decisions and act accordingly.

Based on the results obtained by means of Janoff-Bulman's "Basic concepts scale" test, which gives information about the perception of the inhabitants' personal security, expressed in a scale of a maximum five points, three categories of concepts were revealed:

1) The belief that there is more goodness than evil in the world, that people are the main elements there and the perception of the environment that surrounds them; in this category there are the scales:

- Benevolence of the world;

- Benevolence of people;

2) The belief that, in this world, everything makes sense and all is reasonable, the perception that events happen for certain reasons and justice controls them. In this case, it is convenient to use the scales: 
- Justice;

- Control;

- Randomness;

3) The belief in the value of "self" fits in three concepts: Self - Self value, Self - Self behavior, and Self- Self luck; and corresponds to the scales:

Self-worth;

Self-control;

Luckiness.

The author of the method considers that the more positive the basic concepts of people are, the higher both their resilience level and their capacity for resistance to events will be. It is considered that the positive standard of these beliefs is in the score of three points and a half (3.5).

Table 6

Percentage of interviewed people whose concepts have greater levels $(\geq 3.5)$ or lower levels $(<3.5)$ than the standard

\begin{tabular}{|c|c|c|c|c|c|c|c|}
\hline Scales & Studied group & $<3.5 \%$ & $\geq 3.5 \%$ & Scales & Studied group & $<3.5 \%$ & $\geq 3.5 \%$ \\
\hline \multirow{3}{*}{$\begin{array}{l}\text { Benevolence of } \\
\text { world }\end{array}$} & Puruhas & 22 & 78 & \multirow{3}{*}{ Randomness } & Puruhas & 66 & 34 \\
\hline & Kayambis & 20 & 80 & & Kayambis & 51 & 49 \\
\hline & Otavalos & 42 & 58 & & Otavalos & 47 & 53 \\
\hline \multirow{3}{*}{$\begin{array}{l}\text { Benevolence of } \\
\text { people }\end{array}$} & Puruhas & 37 & 63 & \multirow{3}{*}{ Self-worth } & Puruhas & 34 & 66 \\
\hline & Kayambis & 37 & 63 & & Kayambis & 60 & 40 \\
\hline & Otavalos & 56 & 44 & & Otavalos & 53 & 47 \\
\hline \multirow{3}{*}{ Justice } & Puruhas & 12 & 88 & \multirow{3}{*}{ Self-control } & Puruhas & 22 & 78 \\
\hline & Kayambis & 26 & 74 & & Kayambis & 26 & 74 \\
\hline & Otavalos & 53 & 47 & & Otavalos & 19 & 81 \\
\hline \multirow{3}{*}{ Control } & Puruhas & 27 & 73 & \multirow{3}{*}{ Luckiness } & Puruhas & 24 & 76 \\
\hline & Kayambis & 49 & 51 & & Kayambis & 31 & 69 \\
\hline & Otavalos & 39 & 61 & & Otavalos & 42 & 58 \\
\hline
\end{tabular}

According to the results obtained in the three categories of concepts, it is important to emphasize that (See Table 6):

- On the scales "Benevolence of world", "Control", "Self-control" and "Luckiness" all communities have a greater positive concept.

- On the scales "Benevolence of people", "Justice", "Randomness" and "Selfworth", some of the groups are in the medium lower limit of the scales.

We found statistically valid differences between the Puruhas and Otavalos groups, on the scales: "Benevolence of world", "Benevolence of people", "Justice" and "Randomness". The only scale in which there are valid differences among the three groups is "Justice" (See Table 7).

Table 7

Results of Kruskal-Wallis difference criterion of Janoff-Bulman's "Scale of Basic Concepts"

\begin{tabular}{|l|c|c|c|c|c|}
\hline \multirow{2}{*}{ Scales } & \multicolumn{3}{|c|}{ Medians } & \multirow{2}{*}{$\begin{array}{c}\text { Kruskal Wallis } \\
\text { Criterion }\end{array}$} & \multirow{2}{*}{ Value level } \\
\cline { 2 - 4 } & Puruhas & Kayambis & Otavalos & & \\
\hline Quantity & $N=41$ & $N=35$ & $N=36$ & & .049 \\
\hline Benevolence of world & $3.75^{\star}$ & 4.00 & $3.50^{\star}$ & 6.02 & .039 \\
\hline Benevolence of people & $3.75^{\star}$ & 3.50 & $\mathbf{3 . 2 5}^{\star}$ & 6.50 & .000 \\
\hline Justice & $4.00^{\star} \&$ & $3.75 \&$ & $\mathbf{3 . 2 5}^{\star}$ & 17.12 & \\
\hline
\end{tabular}


Table 7 (End)

\begin{tabular}{|c|c|c|c|c|c|}
\hline \multirow{2}{*}{ Scales } & \multicolumn{3}{|c|}{ Medians } & \multirow{3}{*}{$\begin{array}{c}\text { Kruskal Wallis } \\
\text { Criterion } \\
2.77 \\
\end{array}$} & \multirow{3}{*}{$\begin{array}{c}\text { Value level } \\
.250 \\
\end{array}$} \\
\hline & Puruhas & Kayambis & Otavalos & & \\
\hline Control & 3.75 & 3.50 & 3.75 & & \\
\hline Randomness & $3.00^{*}$ & 3.25 & $3.50^{\star}$ & 7.47 & .024 \\
\hline Self-worth & 3.75 & 3.25 & 3.25 & 2.48 & .290 \\
\hline Self-control & 4.00 & 4.00 & 4.00 & 1.04 & .594 \\
\hline Luckiness & 4.00 & 3.75 & 3.50 & 4.54 & .104 \\
\hline
\end{tabular}

Note. Values that are lower than the standard proposed by the author are given in bold.

* \& = symbols that indicate statistically valid differences

In order to understand the dynamics of each group, which statistically has valid differences in the three groups (See Table 8), we divided each of the studied groups into two subgroups (Clusters), with different combinations of the concepts of "Benevolence of world", "Benevolence of people", "Justice", and "Randomness".

Table 8

Results of the Ward's Cluster Analysis

\begin{tabular}{|l|c|c|c|c|c|c|}
\hline \multicolumn{1}{|c|}{ Scales } & \multicolumn{2}{c|}{ Puruhas } & \multicolumn{2}{c|}{ Kayambis } & \multicolumn{2}{c|}{ Otavalos } \\
\hline Subgroup & $\mathbf{1}$ & $\mathbf{2}$ & $\mathbf{1}$ & $\mathbf{2}$ & $\mathbf{1}$ & $\mathbf{2}$ \\
\hline Benevolence of world & 3.4 & 4.3 & 2.8 & 4.2 & 3.2 & 3.9 \\
\hline Benevolence of people & 3.3 & 4.2 & 3.5 & 3.7 & 3.0 & 3.8 \\
\hline Randomness & 2.7 & 3.3 & 3.3 & 3.4 & 3.8 & 3.1 \\
\hline Justice & 3.9 & 4.5 & 3.1 & 3.9 & 2.9 & 4.2 \\
\hline Amount of people & $\mathbf{1 8}$ & 16 & 9 & $\mathbf{2 4}$ & $\mathbf{2 0}$ & 13 \\
\hline Percentage & $\mathbf{5 3 \%}$ & $\mathbf{4 7 \%}$ & $\mathbf{2 7 \%}$ & $\mathbf{7 3 \%}$ & $\mathbf{6 1 \%}$ & $39 \%$ \\
\hline
\end{tabular}

Note. Values in bold represent those who are the majority in the group of respondents.

Importantly, there is one subgroup that has different characteristics that distinguish it: variable depending on the situation (Subgroup 1), and the other subgroup with the same characteristics in each group (the Puruhas, Kayambis and Otavalos): positive world and medium randomness (Subgroup 2).

\section{Conclusions}

This is an exploratory empirical research that documents the perceptions, opinions and reactions of the target communities: the Puruhas, Kayambis and Otavalos; in order to establish differences in emotional and personal factors of adaptability.

The differences and similarities in emotional and personal factors characteristics are noted among groups of people, despite their living in the same space.

It will be valuable to continue applying this research model in rural and urban areas.

\section{Acknowledgements}

At the present paper, we show the results obtained from the investigation that was publish in the book: Perception and Adaptability of the Population in the Ecuadorian Andes to Climatic Variability Multicultural Comparative Analysis by S. Zavgorodniaya, A. Costales, \& S. Enriquez. We are grateful to the coauthors of this book and the Pontifical Catholyc University of Ecuador for they work and support, which made this investigation and publication possible. 


\section{REFERENCES}

Besedin, A.N., Lipatov, I.I., Timchenko, A.V., \& Shapar', V.B. (1996). Kniga prakticheskogo psikhologa. Moscow: RIP "Original”, firma "Fortuna-press". (In Russ.).

Costales, A.I. (2013) Emotsional'no-lichnostnye faktory adaptirovannosti inostrannykh studentov: Ph.D. in Psychology Thesis. Moscow: RUDN University. (In Russ.).

IPCC (2011). Anexo B: Glosario de términos del Informe Síntesis de Cambio Climático. Retrieved from: http://www.ipcc.ch/pdf/glossary/tar-ipcc-terms-sp.pdf. Accessed: June 6, 2017. (In Spanish).

Janoff-Bulman, R. (1992). Shattered Assumptions: Towards a New Psychology of Trauma. New York: The Free Press.

Mikhailova, O.B., \& Costales Zavgorodniaya, A.I. (2011). Osobennosti proyavleniya psikhosomaticheskikh simptomov u inostrannykh studentov v protsesse adaptatsii k inokul'turnoi srede. Vestnik NGU, 5 (2), 112-117. (In Russ.).

Pinilla Herrera, M.C., Rueda, A., Pinzon, C., \& Sanchez, J. (2012). Percepciones sobre los fenómenos de variabilidad climática y cambio climático entre campesinos del centro de Santander, Colombia. Ambiente y Desarrollo, 16, (31), 25-37. (In Spanish).

Poseck, B.V., Baquero, B.C., \& Vecina Jiménez, M.L. (2006). La experiencia traumática desde la psicología positiva: resiliencia y crecimiento postraumático. Papeles del Psicólogo, 27(1), 40-49. (In Spanish).

Rodríguez, J., Zaccarelli, Davoli, M., \& Pérez, R. (2006). Guía práctica de salud mental en situaciones de desastres. Área de Preparativos para Situaciones de Emergencia y Socorro en Casos de Desastre. Washington D.C.: Serie Manuales y Guías sobre Desastres. (In Spanish).

Rumyantseva, T.V. (2006). Test Kuna. Test “Kto Ya?»”(M.Kun, T.Makpartlend; modifikatsiya T.V.Rumyantsevoi). Psikhologicheskoe konsul'tirovanie: diagnostika otnoshenii v pare (pp. 82-103). St. Petersburg. (In Russ.).

Timofeev, V.I., \& Filimonenko, Yu.I. (1995). Kratkoe rukovodstvo prakticheskomu psikhologu po ispol'zovaniyu tsvetovogo testa M. Lyushera. St. Petersburg: Imaton. (In Russ.).

Villalba Quesada, C. (2004). El Concepto de Resiliencia. Aplicaciones en La Intervención Social. Sevilla: Universidad Pablo de Olvide. (In Spanish).

Zavgorodniaya, S., Costales, A., \& Enriquez, S. (2016). Percepción y adaptabilidad de la población de los Andes Ecuatorianos a la variabilidad climática - Análisis Comparativo Multicultural. Quito: PUCE. (In Spanish).

Article history:

(C) Costales Zavgorodniaya, A.I., 2017

Received 12 March 2017

Revised 7 June 2017

Accepted 14 June 2017

\section{For citation:}

Costales Zavgorodniaya, A.I. (2017). Emotional and Personal Factors of Adaptability of the Population in the Ecuadorian Andes. RUDN Journal of Psychology and Pedagogics, 14 (3), 339-352. DOI 10.22363/2313-1683-2017-14-3-339-352

\section{Bio Note:}

Anna I. Costales Zavgorodniaya - Ph.D. in psychology, associate professor of Theological and Philosophy Department of the Pontifical University of Ecuador (Quito, Ecuador). E-mail: annacostales@gmail.com 


\title{
ЭМОЦИОНАЛЬНО-ЛИЧНОСТНЫЕ ФАКТОРЫ АДАПТИРОВАННОСТИ НАСЕЛЕНИЯ В АНДАХ ЭКВАДОРА
}

\author{
А.И. Косталес Завгородняя \\ Понтифический католический университет Эквадора \\ ул. 12 Октября \# 1076 у Рока, Кито, Эквадор, 170525
}

\begin{abstract}
Авторами статьи был применен междисциплинарный подход, чтобы понять и исследовать восприятие и адаптированность населения в Андах Эквадора к климатической изменчивости. Исследование было направленно на изучение трех этнических групп в Эквадоре: пуруаэ, каямбэ и отавало, которые проживают на склонах гор вплоть до вершин вулканов на высоте более 2600 метров над уровнем моря. Для установления климатической изменчивости были собраны и проанализированы метеорологические данные за период более 30 лет, также определена динамика землепользования и изменения естественного растительного покрова двух последних десятилетий. Эта информация, полученная из окружающей среды, сравнивалась с информацией, полученной при анкетировании местных жителей относительно их воспринятия изменений в климате и в их образе жизни, а также с данными психологического тестирования, направленного на исследование уровней адаптированности.

Данное психологическое исследование основывается на предположении о том, что адаптированность связана как с эмоциональными и личностными особенностями человека и группы; так и с окружающей средой. Адаптация является процессом, посредством которого личность и сообщества ассимилируют новые способы выживания и, следовательно, они приспосабливаются к новым ситуациям. Изучая эти особенности в определенной этно-культурной группе, возможно смоделировать адаптационный потенциал жителей этих групп в условиях опасности и их возможную уязвимость.
\end{abstract}

Ключевые слова: эмоционально-личностные факторы, адаптированность, Анды Эквадора, межкультурный сравнительный анализ

(C) Косталес Завгородняя А.И., 2017

\section{История статьи:}

Поступила в редакцию: 12 марта 2017

Принята к печати: 14 июня 2017

\section{Для цитирования:}

Косталес Завгородняя А.И. Эмоционально-личностные факторы адаптированности населения в Андах Эквадора // Вестник Российского университета дружбы народов. Серия: Психология и педагогика. 2017. T. 14. № 3. C. 339-352. DOI 10.22363/2313-1683-2017-14-3339-352

\section{Сведения об авторе:}

Анна И. Косталес Завгородняя - кандидат психологических наук, преподаватель кафедры теологии и философии Понтифического католического университета Эквадора (Кито, Эквадор). E-mail: annacostales@gmail.com 